\title{
POLA PENGGUNAAN SITUS JEJARING SOSIAL SEBAGAI MEDIA PEMBELAJARAN UNTUK MAHASISWA
}

\author{
Almed Hamzah \\ Jurusan Teknik Informatika, Fakultas Teknologi Industri,Universitas Islam Indonesia \\ Jl. kaliurang Km. 14,5, Ngemplak, Sleman, Yogyakarta, 55584 \\ Email : almed.hamzah@uii.ac.id
}

\begin{abstract}
Social networking sites are very popular. At this time a lot of social networking sites that emerge and evolve. Some of which the most popular are Facebook, Twitter, path, myspace. These sites are popular because it has many users from various groups including the student. Students including active users of social networking sites. The majority of the students even already have an account at more than one site of several social networking sites. Social networking sites can be used by students for a variety of purposes, one of them as a medium of learning. This research is a case study to explore the use of social networking sites as a medium of learning among the students. A total of 42 students were respondents in this study. Results of the analysis found that social networking sites are already quite familiar among students as a means to socialize as well as a learning medium. In addition, it features a social networking site which is used as a medium of learning is not much different from the usual features that are used for other purposes.
\end{abstract}

Keyword: Adoption of Technology, E-Learning, Students, Social Networking Sites, Media Learning

\section{PENDAHULUAN}

Saat ini situs jejaring sosial banyak sekali macamnya. Diantara yang paling populer adalah Facebook, LinkedIn, Pinterest, Instagram, Twitter (Duggan, Ellison, Lampe, Lenhart, \& Madden, 2015). Situs jejaring sosial tersebut memiliki jumlah pengunjung (visitor) yang relatif lebih besar daripada situs lainnya dan memiliki kecenderungan untuk terus meningkat. Hal ini dikarenakan ada sisi menarik dari situs tersebut yaitu adanya interaksi sosial yang lebih personal dibandingkan jenis situs lainnya. Seseorang bisa berkomunikasi dengan banyak orang dalam satu waktu tanpa terhalang oleh ruang dan waktu. Selain itu, seseorang juga bisa mendapatkan teman baru tanpa harus berkenalan dan bertemu secara langsung.

Situs jejaring sosial digunakan oleh banyak orang dengan berbagai tujuan. Sopiah (Sopiah, 2013) membagi tujuan tersebut menjadi empat kategori yaitu kesenangan, komunikasi, informasi, dan transaksi. Kesenangan berarti situs jejaring sosial digunakan sebagai media penyaluran hobi dan menghabiskan waktu. Komunikasi dan informasi berarti situs jejaring sosial digunakan untuk tujuan berbagi pengetahuan secara interaktif dengan teman yang tergabung di dalam network. Sedangkan transaksi berarti situs jejaring sosial digunakan untuk tujuan jual-beli produk, pemasaran, after-sales services dan sebagainya.

E-Learning saat ini sedang marak digunakan untuk membantu proses pembelajaran mahasiswa. Bahkan e-learning telah berkembang sebagai paradigma baru dalam pendidikan modern (Sun, Tsai, Finger, Chen, \& Yeh, 2008). Di Indonesia, meskipun e-learning masih diterapkan sebagai supporting tools dalam kegiatan belajar mengajar akan tetapi penyebarannya sudah meluas dan semakin berkembang. 
Fleksibilitas menjadi kata kunci dalam penyelenggaraan kegiatan belajar mengajar melalui e-learning. Baik dosen maupun mahasiswa dapat tetap menjalin komunikasi di luar kelas perkuliahan. Selain itu, dosen dan mahasiswa juga dapat menjalin komunikasi meskipun lokasi mereka berjauhan.

Situs jejaring sosial adalah salah satu jenis aplikasi online yang memungkinkan penggunanya memposting informasi mengenai profil dirinya, termasuk nama, foto dan materi lainnya untuk dilihat oleh sesama pengguna. Selain itu, mereka juga dapat berkomunikasi satu sama lain dalam cara-cara yang inovatif (Pempek, Yermolayeva, \& Calvert, 2009. Bahkan pengguna bisa melacak siapa saja yang melihat content yang dibagikannya (Boyd \& Ellison, 2007). Halhal inilah yang menyebabkan banyak orang, terutama pengguna internet, sangat tertarik untuk menggunakan situs jejaring sosial untuk berbagi informasi dan berkomunikasi. Dan semakin hari semakin banyak orang yang tertarik menggunakan situs jejaring sosial sehingga kepopuleran situs jejaring sosial semakin meningkat.

Dua teknologi ini, yaitu e-learning dan situs jejaring sosial, yang sama-sama populer dengan kadar dan audience yang berbeda pada saat ini mulai digabungkan untuk menjadi sebuah paradigma tersendiri dalam proses pembelajaran di universitas. Penggunaan situs jejaring sosial sebagai media e-learning selama ini mulai banyak digunakan dibeberapa kampus. Namun begitu belum banyak penelitian yang mengungkap tentang pola penggunaan situs jejaring sosial ini, terutama sebagai media pembelajaran untuk membantu terselenggaranya proses belajar mengajar yang lebih efektif dan efisien. Dengan situs jejaring sosial, sebenarnya dosen dapat menjangkau dan tetap berkomunikasi dengan mahasiswanya dimanapun mahasiswa tersebut berada (Moran, Seaman, \& Tinti-Kane, 2011. Selama masih terdapat koneksi internet, maka situs jejaring sosial adalah media pembelajaran yang efektif dalam penyelenggaraan kegiatan belajar mengajar. Penggunaan situs jejaring sosial sebagai media pembelajaran paling tidak memenuhi salah satu kriteria penggunaan media pembelajaran yang efektif menurut (Daryanto, 2010) yaitu mengatasi keterbatasan ruang, waktu, tenaga dan daya indra.

Dalam penerapan sebuah teknologi, pencarian pola sangat penting agar didapatkan sebuah model yang menggambarkan situasi ketika sebuah teknologi tersebut diimplementasikan. Pada akhirnya model tersebut bisa diduplikasi ke dalam situasi yang sama di tempat yang lain. Melalui studi kasus, penelitian ini akan mengeksplorasi dan mengungkap pola penggunaan situs jejaring sosial sebagai media pembelajaran untuk mahasiswa.

Paper ini memiliki struktur sebagai berikut. Bagian pertama berisi pendahuluan dan latar belakang penelitian. Bagian kedua menjelaskan tinjauan pustaka terhadap penelitian-penelitian terdahulu. Bagian ketiga membahas tentang metode penelitian yang digunakan. Bagian keempat membahas tentang hasil dan temuan penelitian diikuti dengan bagian terakhir yaitu kesimpulan dan rekomendasi.

\section{TINJAUAN PUSTAKA}

\subsection{Media Pembelajaran}

Secara sederhana, media pembelajaran dapat didefinisikan sebagai alat dan bahan yang digunakan dalam kegiatan pembelajaran (Daryanto, 2010). Alat dan bahan tersebut digunakan sebagai perantara bagi Dosen untuk berkomunikasi dengan mahasiswanya.

Peran media pembelajaran sangat penting sebagai penyampai ide (yang berasal dari Dosen pada satu sisi) untuk dimengerti oleh Mahasiswa pada sisi yang lain. Tantangan terbesar dari Dosen adalah membuat atau memanfaatkan media dengan sebaik-baiknya agar ide atau materi yang ingin diajarkan menjadi mudah diserap dan dipahami oleh Mahasiswa. 
Berdasarkan

penelitian-penelitian sebelumnya yang dilakukan oleh Cheung (Cheung, Chiu, \& Lee, 2011), Brady (Brady, Holcomb, \& Smith, 2010), Shen dan Khalifa (Shen \& Khalifa, 2010) terungkap bahwa dibalik kepopuleran situs jejaring sosial tidak banyak penelitian dilakukan di dalamnya, apalagi penelitian yang secara khusus mengaitkan antara penggunaan situs jejaring sosial dengan dunia akademis, sebagai media pembelajaran, seperti yang diutarakan oleh Brady (Brady et al., 2010). Bicen (Bicen, 2011) bahkan menyarankan agar penelitian tentang pola penggunaan situs jejaring sosial di dunia akademis, terutama di perguruan tinggi, lebih banyak dilakukan karena penggunaan situs jejaring sosial menjadi semakin penting di dalam kehidupan seharihari mahasiswa.

Situs jejaring sosial (SJS) adalah layanan berbasis web yang memungkinkan seseorang untuk membangun profil pribadinya yang bersifat publik atau semi-publik di dalam sebuah sistem yang terbatas, menyampaikan kepada orang lain mengenai orang-orang yang terhubung dengannya, serta melihat dan melacak daftar pertemanan baik yang dibuat sendiri atau dibuat oleh orang lain (Boyd \& Ellison, 2007). Inilah yang membuat perbedaan situs jejaring sosial dengan jenis situs lainnya, seperti situs berita, portal, ecommerce. Pada situs jejaring sosial terjadi interaksi sosial antar pengguna yang sifatnya lebih personal dan mendalam. Oleh karenanya, terdapat masalah dan dampak sosial yang menyertainya.

\subsection{Penggunaan Situs Jejaring Sosial}

Situs jejaring sosial dibuat dengan tujuan meningkatkan intensitas interaksi sosial (Shen \& Khalifa, 2010) yang sudah berlangsung di dunia nyata. Dalam hal ini pola interaksi dan komunikasi yang terjadi di situs jejaring sosial tidak jauh berbeda dengan yang terjadi di dunia nyata. Teman yang ada di situs jejaring sosial pun sebenarnya adalah teman yang memang sudah dikenal di dunia nyata, walaupun ada beberapa pertemanan yang hanya dilakukan di dunia maya. Dalam situs jenis ini memang seseorang dapat melakukan pertemanan secara online tanpa pernah bertemu sebelumnya (Boyd \& Ellison, 2007).

Menurut Shen dan Khalifa (Shen \& Khalifa, 2010), situs jejaring sosial memiliki dampak yang besar bagi kehidupan seseorang, baik dari sisi sosial maupun komersial. Untuk orang yang lebih muda (youth), situs ini telah menjadi alat untuk membangun identitas dan memelihara hubungan sosial dengan teman-temannya (Shen \& Khalifa, 2010). Dalam beberapa kasus, situs ini menjadi tempat berkumpul utama atau primary gathering places (Hoy \& Milne, 2010). Hal ini dapat disebabkan oleh banyaknya orang yang terpisah secara geografis sehingga tidak dimungkinkan untuk bertatap muka secara langsung.

Penggunaan situs jejaring sosial selain membawa manfaat juga memiliki dampak negatif. Menurut Rouis (Rouis, Limayem, \& Salehi-Sangari, 2011), penggunaan situs jejaring sosial yang berlebihan oleh remaja, dalam hal ini mahasiswa, dapat menurunkan prestasi akademis mereka. Hal ini menjadi dua hal yang bertolak belakang ketika perguruan tinggi berlomba-lomba memanfaatkan situs jejaring sosial ini sebagai salah satu saluran komunikasi dengan mahasiswa. Mungkin hal ini baik bagi bisnis, tetapi tidak bagi mahasiswa. Namun begitu, bagaimanapun juga situs jejaring sosial telah menjadi bagian dari kehidupan mahasiswa. Oleh karenanya perlu dikaji langkah-langkah yang harus dilakukan agar terjadi keselarasan dengan aspek akademisnya, bukan sebaliknya.

\subsection{Motivasi Seseorang Menggunakan Situs Jejaring Sosial}

Salah satu alasan utama seseorang menggunakan situs jejaring sosial adalah keinginan untuk berkomunikasi dan terkoneksi secara instan dengan orang lain (Cheung et al., 2011). Pola komunikasi pada masa sekarang ini yang menuntut segala sesuatunya dikerjakan dengan cepat membuat 
situs jejaring sosial menjadi salah satu sarana yang sangat membantu dan memecahkan sebagian tantangan komunikasi yang serba cepat tersebut.

Selain alasan yang utama tersebut berkembang pula motivasi lainnya seperti berbagi informasi, hiburan, dan bertransaksi (Sopiah, 2013) $\square$, memelihara hubungan interpersonal dan memperluas jaringan pertemanan (Cheung et al., 2011). Khusus pada orang usia remaja dan dewasa dini, sosial media bahkan digunakan untuk membantu pencarian jati diri (self-identity) dengan cara memposting content tertentu untuk kemudian menerima tanggapan dari teman-temannya di situs jejaring sosial. Tanggapan-tanggapan tersebut kemudian menjadi gambaran atau citra diri dari seorang remaja di hadapan para temannya (Pempek et al., 2009).

\subsection{Penggunaan Situs Jejaring Sosial Di Bidang Pendidikan}

Tidak banyak penelitian yang membahas tentang penggunaan situs jejaring sosial dalam dunia pendidikan, terutama sebagai media pembelajaran. Beberapa penelitian yang pernah dilakukan terkait dengan penggunaan situs jejaring sosial dalam dunia pendidikan mengungkapkan pola penggunaan situs jejaring sosial dilihat dari segi waktu, rata-rata mahasiswa menghabiskan 30 menit setiap harinya untuk beraktivitas di situs jejaring sosial dengan berbagai keperluan termasuk yang menyangkut kegiatan akademik (Pempek et al., 2009), (Ellison, Steinfield, \& Lampe, 2007). Namun, lamanya waktu ini semakin meningkat setiap harinya bahkan hingga 4 jam per hari (Bicen, 2011).

Mengenai aktivitas di situs jejaring sosial, banyak sekali aktivitas yang dilakukan oleh mahasiswa ketika menggunakan situs jejaring sosial, termasuk yang berkaitan dengan pendidikannya. Menurut Shen dan Khalifa (Shen \& Khalifa, 2010) minimal ada sebelas aktivitas yang teridentifikasi dilakukan oleh mahasiswa dalam situs jejaring sosial. Dari ke sebelas aktivitas ini yang berhubungan dengan dunia pendidikan diantaranya adalah mencari informasi, mempelajari bagaimana sesuatu bekerja, berbagi informasi dengan teman, menggali ide, dan memecahkan sebuah masalah.

Pada umumnya, aktivitas pembelajaran yang menggunakan komputer bersifat mandiri (Daryanto, 2010) $\square$. Hal ini berlaku juga untuk penggunaan situs jejaring sosial sebagai media pembelajaran bagi mahasiswa. Pola pembelajaran yang terbentuk nantinya akan lebih banyak menuntut mahasiswa untuk belajar secara mandiri.

Dalam kerangka adopsi e-learning di kampus yang dikembangkan oleh Russell (Russell, 2009) teknologi dipandang sebagai pembentuk aktivitas belajar mengajar yang baru seperti tampak dalam Gambar 1. Dalam konteks penelitian ini maka situs jejaring sosial dapat dipandang sebagai teknologi baru yang membentuk sebuah aktivitas belajar mengajar dan tipe pembelajaran yang juga baru bagi mahasiswa.

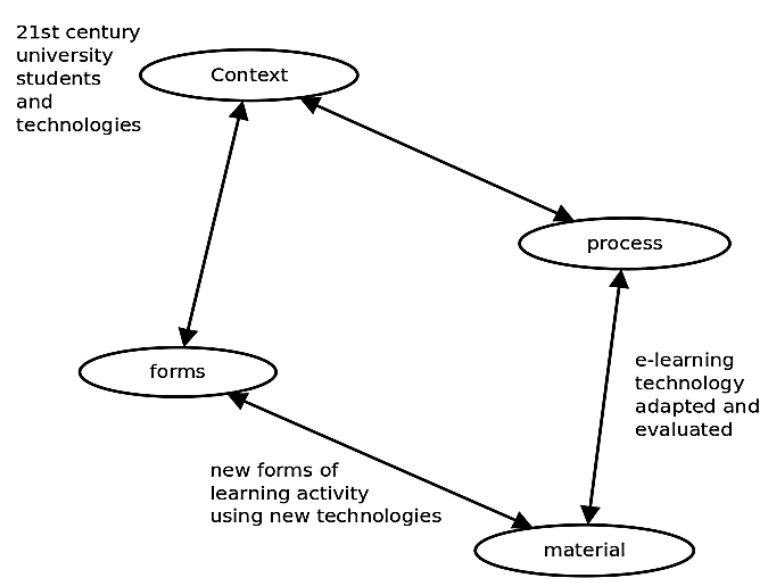

Gambar 1. Kerangka Adopsi E - Learning.

Bagaimanapun juga mahasiswa sudah sangat familiar dengan situs jejaring sosial. Oleh karenanya, situs ini harus bisa dimanfaatkan agar pembelajaran dapat lebih terakses (Liu, 2010). Berdasarkan pemaparan dari penelitian-penelitian sebelumnya yang telah diuraikan hasilnya ternyata belum ada penelitian yang secara khusus melakukan penyelidikan terhadap fenomena penggunaan situs jejaring sosial sebagai media 
pembelajaran. Oleh karena itu, penelitian di bidang ini sangat menarik dan layak untuk dilakukan.

\section{METODE PENELITIAN}

Penelitian ini menggunakan pendekatan metode studi kasus (MSK). Pendekatan ini dipilih selain karena sesuai dengan pertanyaan penelitian yang diajukan (how and why) juga untuk melihat lebih dalam kepada individu per kasusnya sehingga didapatkan kesimpulan dan generalisasi yang lebih baik.

Jumlah kasus yang diangkat dalam penelitian ini lebih dari satu sehingga metode studi kasus yang digunakan adalah multiplecase. Dalam metode jenis ini digunakan teknik analisis lintas kasus (cross-case analysis). Pada analisis lintas kasus tiap kasus akan dibandingkan satu sama lain dan melihat perbedaan maupun kesamaan diantara kasuskasus tersebut untuk selanjutnya diambil kesimpulan yang mencakup keseluruhan kasus dan berkaitan dengan tema penelitian. Sementara itu unit analisis yang digunakan adalah penggunaan situs jejaring sosial oleh mahasiswa.

Metode pengumpulan data yang digunakan adalah observasi, wawancara, dan dokumentasi. Observasi dilakukan terhadap mahasiswa peserta mata kuliah yang menggunakan situs jejaring sosial. Wawancara semi terstruktur akan dilakukan terhadap mahasiswa tersebut yang bersedia untuk menjadi responden atau narasumber. Sebelum wawancara akan disusun terlebih dahulu panduan pertanyaan yang akan diajukan selama wawancara. Panduan tersebut tidak bersifat mengikat dan dapat dikembangkan sesuai dengan kondisi pada saat wawancara dilakukan. Sementara itu dokumentasi dilakukan untuk mengumpulkan dokumen-dokumen terkait wawancara dan tema penelitian. Observasi akan dilakukan terhadap pola penggunaan situs jejaring sosial dalam pembelajaran sesuai dengan kebutuhan data penelitian.

\subsection{Subjek Penelitian dan Teknik Pengambilan Sampel Penelitian}

Sumber data yang diperlukan selama penelitian ini berlangsung akan disesuaikan dengan fokus dan tujuan dari penelitian. Teknik pengambilan sampel yang digunakan adalah gabungan antara purposif dan kuota. Hal ini agar penelitian berjalan dengan efisien dan sesuai dengan sumber daya yang tersedia.

Penelitian ini akan mengambil sampel mahasiswa Universitas Islam Indonesia peserta kelas matakuliah yang menggunakan situs jejaring sosial sebagai media pembelajarannya terutama dari Jurusan Teknik Informatika. Diharapkan ada 40 sampai dengan 50 narasumber (responden) yang akan berpartisipasi dalam penelitian ini.

\subsection{Metode Analisis Data}

Sebelum dilakukan analisa lintas kasus (cross-case analysis) data akan diolah secara statistik untuk menghasilkan deskripsi kuantitatif. Kemudian analisis data dilakukan dengan metode cross-case analysis. Dalam metode ini, hasil analisa setiap kasus akan dibandingkan satu sama lain untuk mendapatkan pemahaman yang menyeluruh tentang masalah yang sedang diteliti.

Pembandingan ini dilakukan untuk mencari pola yang sama yaitu berupa kesamaan maupun perbedaan yang muncul dalam setiap kasusnya. Perbandingan ini berdasarkan pertanyaan penelitian yang dibuat, yaitu motivasi, hal-hal apa saja yang dilakukan, serta pola penggunaannya.

Hasil dari analisa lintas kasus adalah sebuah rekomendasi / model / framework tentang pola penggunaan situs jejaring sosial sebagai media pembelajaran untuk mahasiswa. Rekomendasi ini diharapkan bisa digunakan atau diterapkan di tempat lain dengan lingkungan yang hampir sama dengan lingkungan tempat penelitian ini dilaksanakan (duplikasi hasil penelitian). 


\section{HASIL DAN PEMBAHASAN}

\subsection{Pengambilan Data}

Penelitian ini dilaksanakan pada bulan Juni-Juli 2015. Pengambilan data dilakukan dengan cara wawancara semi terstruktur dengan menggunakan panduan pertanyaan yang di ajukan ke responden / narasumber yang pernah mengikuti kelas perkuliahan tertentu yang menggunakan situs jejaring sosial sebagai salah satu media pembelajarannya. Pengambilan data dilakukan secara serentak kepada mahasiswa yang menjadi responden. Data yang berhasil terkumpul sebanyak 42 responden.

\subsection{Deskripsi Responden}

Responden yang menjadi narasumber dalam penelitian ini adalah mahasiswa Jurusan Teknik Informatika Universitas Islam Indonesia. Sebaran usia responden mayoritas masih berusia 19 sampai dengan 20 tahun (84\%). Kelompok kedua adalah usia 21 tahun (12\%). Kelompok terakhir adalah usia di bawah 19 tahun dan di atas 21 tahun yaitu masing-masing memiliki prosentase $2 \%$. Mayoritas responden berjenis kelamin lakilaki dengan prosentase sebesar $71 \%$ dan yang lainnya adalah perempuan dengan prosentase sebesar 29\%.

Mayoritas mahasiswa yang menjadi responden berada di tahun ke-2 dan tahun ke3 kuliahnya (43\% dan 48\%). Sisanya adalah mahasiswa yang sudah memasuki tahun ke-4 dan sesudahnya (7\% dan 2\%). Berdasarkan data tersebut maka dalam penelitian ini tidak melibatkan mahasiswa baru (freshmen). Hal ini berarti pengalaman belajar dan menggunakan media pembelajaran dalam sebuah kelas perkuliahan sudah cukup didapatkan oleh para mahasiswa yang menjadi responden tersebut. Mereka sudah pernah mengunduh materi dari dosen, mencari informasi dari internet, mengumpulkan tugas secara online, dan aktivitas lainnya terkait penggunaan media pembelajaran di kelas dan di luar kelas perkuliahan.

\subsection{Penggunaan Situs Jejaring Sosial}

Banyaknya jumlah situs jejaring sosial yang berkembang saat ini memberikan lebih banyak pilihan kepada pengguna internet untuk memilih salah satu atau beberapa darinya. Meskipun begitu, tampaknya mahasiswa sebagai pengguna situs jejaring sosial kurang berminat untuk menggunakan terlalu banyak (multiple) situs jejaring sosial dalam satu waktu. Mayoritas pengguna memilih untuk menggunakan hanya 1 atau paling banyak 2 jenis situs jejaring sosial dalam satu waktu (19\% dan 21\%). Hal ini dapat disebabkan oleh beberapa hal, diantaranya adalah banyaknya teman-teman pengguna dalam satu komunitas yang menggunakan satu jenis situs jejaring sosial tertentu untuk menjalin komunikasi.

Diantara situs jejaring sosial yang banyak digunakan ada beberapa yang sangat populer dan paling banyak penggunanya. Bahkan dalam konteks penelitian ini, Facebook masih menduduki peringkat pertama dalam hal banyaknya pengguna. Sebanyak $85 \%$ responden merupakan pengguna situs jejaring sosial ini. Situs ini memang sangat populer di dunia dan memiliki paling banyak pengguna dibandingkan situs-situs jejaring sosial sejenis. Bahkan diperkirakan jumlah penggunanya terus meningkat per harinya (Bicen, 2011). Temuan ini selaras dengan penelitian lainnya yang menemukan bahwa facebook adalah situs jejaring sosial yang paling banyak digunakan bahkan di dunia akademis (Moran et al., 2011).

Diperingkat kedua, untuk situs sejenis, adalah Twitter (42\%) dan Instagram (45\%). Kedua situs jejaring sosial ini menjadi pilihan alternatif terbanyak yang dipilih oleh responden karena memiliki kekhasan tersendiri yang tidak dimiliki situs jejaring sosial sejenis lainnya. Twitter memiliki kekhasan dalam hal pembatasan karakter untuk sekali posting sebanyak 140 karakter. Sementara Instagram memiliki fitur-fitur khusus untuk berbagi gambar.

Tempat mahasiswa biasa mengakses situs jejaring sosial. Mahasiswa paling sering 
mengakses situs jejaring sosial dari rumah/kos $(69 \%)$. Kampus menjadi tempat kedua paling banyak dipilih untuk mengakses situs jejaring sosial (30\%). Di luar itu mahasiswa mengakses situs jejaring sosial di restoran (9\%) dan tempat wisata (7\%). Selebihnya mahasiswa biasa mengakses di tempat-tempat lainnya dimanapun mereka sedang berada $(30 \%)$.

Lama waktu akses situs jejaring sosial oleh mahasiswa. Terlihat dalam gambar tersebut banyak sekali mahasiswa yang mengakses situs jejaring sosial lebih dari 7 jam (28\%). Lama waktu ini sudah sangat jauh meningkat dibandingkan hasil temuan dari penelitian sejenis yang dilakukan oleh (Pempek et al., 2009) yang menemukan bahwa rata-rata mahasiswa paling lama menghabiskan waktu untuk menggunakan situs jejaring sosial adalah kurang dari 2 jam saja.

Ada beberapa aktivitas mahasiswa ketika mengakses situs jejaring sosial. Chatting merupakan aktivitas yang paling banyak dilakukan oleh mahasiswa ketika mengakses situs jejaring sosial (83\%). Disamping karena kebutuhan, fasilitas chatting juga disediakan oleh mayoritas situs jejaring sosial untuk memudahkan penggunanya berkomunikasi dengan teman sesama pengguna situs jejaring sosial.

Setelah itu berturut-turut mahasiswa melakukan aktivitas yang lainnya, yaitu upload foto (7\%), update info (28\%), dan bermain game (2\%).

Banyak ragam media pembelajaran sudah pernah digunakan oleh mahasiswa. Perangkat laptop menjadi media pembelajaran yang paling banyak digunakan oleh mahasiswa dengan prosentase sebesar 100\%. Di peringkat kedua adalah internet (85\%) dan handphone / smartphone (83\%). Hal ini mengindikasikan bahwa mahasiswa sudah familiar dengan perangkat-perangkat teknologi untuk mendukung kegiatan pembelajarannya.

Aktivitas yang dilakukan oleh mahasiswa ketika menggunakan media pembelajaran adalah mencari informasi secara online (47\%). Banyaknya sumber-sumber informasi yang mendukung dan berkaitan dengan aktivitas pembelajaran yang tersedia secara online adalah salah satu faktor terkuat yang menyebabkan banyaknya prosentase mahasiswa yang melakukan aktivitas ini. Aktivitas selanjutnya adalah presentasi (14\%), berinteraksi (4\%) dan menyampaikan materi $(7 \%)$. Ketiga aktivitas ini dilakukan baik oleh dosen maupun mahasiswa.

\subsection{Analisa Studi Kasus (Kronologi)}

Situs jejaring sosial adalah sebuah bentuk kemajuan teknologi yang memungkinkan komunikasi antar manusia menjadi lebih kaya (enrichment) tanpa mengenal perbedaan waktu dan lokasi geografis. Beragam fitur disediakan di dalam situs jejaring sosial, seperti misalnya upload gambar, chatting, membuat grup, membuat page, dan lain sebagainya.

Media pembelajaran di satu sisi sangat penting dalam mendukung terselenggaranya proses pendidikan dan transfer pengetahuan yang baik. Tanpa adanya media pembelajaran maka proses pembelajaran bisa jadi kurang bervariasi dan monoton. Selain itu, penggunaan media pembelajaran juga membantu pengajar untuk menyampaikan materi dengan lebih baik, efektif dan efisien. Lebih jauh lagi, media pembelajaran dapat meningkatkan pemahaman mahasiswa terhadap suatu materi serta pada akhirnya dapat meningkatkan prestasi belajar mahasiswa.

Sebelum berkembangnya internet dan situs jejaring sosial, media pembelajaran tidak dapat digunakan secara maksimal baik oleh pendidik maupun peserta didik. Sebagai pendidik, dosen akan mengalami kesulitan dalam membagikan materi dan tugas yang diberikan sebab pertemuan hanya dapat dilakukan di kelas atau jika tidak dosen mahasiswa harus bertemu langsung secara fisik di suatu tempat. Di sisi lain, mahasiswa sebagai peserta didik kesulitan mengakses materi dari dosen. Selain itu, media 
pembelajaran yang tersedia tidak memungkinkan terjalinnya komunikasi antara dosen dan mahasiswa di luar kelas perkuliahan.

Setelah adanya internet dan berkembangnya situs jejaring sosial, maka masalah-masalah tersebut bisa diatasi pada tingkatan tertentu. Berbagai fasilitas yang disediakan oleh situs jejaring sosial memungkinkan adanya komunikasi terbuka antara dosen dan mahasiswa, seperti fasilitas group, chatting, forum, dan sebagainya. Selain itu, aktivitas terkait pembagian materi, pengumpulan tugas bisa dilakukan dengan lebih baik dan terkoordinir.

\subsection{Analisa Lintas Kasus}

\subsubsection{Motivasi Menggunakan Situs Jejaring Sosial sebagai Media Pembelajaran}

Bagian ini akan membahas tentang motivasi menggunakan situs jejaring sosial, terutama sebagai media pembelajaran. Mayoritas mahasiswa menggunakan situs jejaring sosial untuk menjalin komunikasi dengan teman-temannya (76\%) serta mencari informasi yang diinginkan (80\%). Hal ini sudah selaras dengan aktivitas yang dilakukan oleh mahasiswa ketika mereka mengakses situs jejaring sosial, yaitu chatting dan upload informasi.

Situs jejaring sosial digunakan sebagai sarana berbagi informasi antara dosen dan mahasiswa maupun antar sesama mahasiswa. Dosen membagikan informasi mengenai materi kuliah, pelaksanaan perkuliahan, dan tugas-tugas yang dikerjakan oleh mahasiswa. Sementara itu mahasiswa akan membagikan informasi lainnya yang terkait dengan materi perkuliahan. Menurut mahasiswa sebagai pengguna situs jejaring sosial sebagai media pembelajaran, situs jejaring sosial dianggap mampu untuk menyebarkan informasi secara cepat, bahkan bisa dikatakan informasi tersebut tersebar secara real-time. Walaupun pada kenyataannya dapat terkendala oleh koneksi internet yang tidak stabil. Terdapat motivasi yang berbeda-beda dari mahasiswa terkait penggunaan situs jejaring sosial sebagai media pembelajaran.

\subsubsection{Aktivitas dalam Situs Jejaring Sosial Sebagai Media Pembelajaran}

Pada saat menggunakan situs jejaring sosial sebagai media pembelajaran, aktivitas yang paling banyak dilakukan adalah upload materi (78\%). Aktivitas ini dimulai ketika dosen mengunggah (upload) materi yang bersesuaian untuk dipelajari oleh mahasiswa yang berada dalam satu group. Selanjutnya mahasiswa akan mengunduh (download) materi tersebut untuk dipelajari secara offline.

Jika ada hal yang kurang jelas atau perlu ditanyakan, maka mahasiswa akan berkomunikasi dengan dosen maupun sesama mahasiswa melalui fasilitas chatting maupun forum. Kedua aktivitas ini masing-masing memiliki prosentase sebesar $45 \%$ dan $66 \%$. Chatting adalah percakapan secara real-time antara dua orang melalui layar komputer (www. webopedia. com, 2015). Oleh karenanya, aktivitas ini lebih bersifat pribadi daripada komunikasi yang dilakukan di dalam forum. Forum adalah ruang komunikasi yang lebih terbuka daripada chatting yang terjadi antara dosen dan semua mahasiswa yang tergabung di dalam sebuah kelas. Sebuah pesan yang di-posting oleh dosen atau salah satu mahasiswa akan bisa dilihat oleh semua orang yang tergabung dalam forum tersebut.

\subsubsection{Pola Penggunaan Situs Jejaring Sosial sebagai Media Pembelajaran}

Sebagian pola penggunaan sudah diungkap di bagian awal bab ini. Bagian ini akan menambahkan tentang pola penggunaan situs jejaring sosial secara khusus sebagai media pembelajaran. Sebagian besar mahasiswa sudah pernah mengikuti kelas kuliah yang menggunakan situs jejaring sosial sebagai salah satu media pembelajarannya $(76 \%)$.

Fasilitas yang paling banyak digunakan oleh mahasiswa ketika menggunakan situs jejaring sosial sebagai media pembelajaran adalah fasilitas "group" (57\%) dan chat 
(28\%). "Group" adalah fasilitas yang disediakan oleh situs jejaring sosial untuk memudahkan sekumpulan orang / keluarga / rekan kerja untuk terkoneksi satu sama lain dalam sebuah ruang khusus (dedicated spaces) (www. web. facebook. com, 2015). Berbeda dengan fasilitas group yang lebih menekankan pada aktivitas berbagi informasi dengan anggota group, fasilitas chatting adalah sarana bagi pengguna situs jejaring sosial untuk berkomunikasi secara real-time dengan teman / koleganya. Kedua hal ini selaras dengan motivasi terbesar mahasiswa dalam menggunakan situs jejaring sosial, yaitu informasi dan komunikasi. Maka situs jejaring sosial yang memiliki dua fitur ini layak untuk digunakan sebagai media pembelajaran.

Group biasanya dibentuk oleh dosen dan beranggotakan para mahasiswa yang mengikuti kelas matakuliah dosen tersebut. Group digunakan oleh dosen untuk berbagi materi dan informasi terkait perkuliahan yang ditujukan kepada semua peserta / anggota, seperti informasi tugas, penggantian kelas, atau materi tambahan. Sementara itu fasilitas chatting biasanya digunakan oleh mahasiswa untuk berkomunikasi dengan dosennya dan menanyakan secara langsung hal-hal terkait perkuliahan atau informasi yang di-posting oleh dosen di Group.

Selain Group dan Chat sebenarnya masih banyak fasilitas lain yang disediakan oleh situs jejaring sosial, misalnya Pages (14\%), Hashtag (7\%), (berbagi) foto dan video (masing-masing 4\%), dan File (9\%). Namun fasilitas-fasilitas ini masih jarang dimanfaatkan oleh mahasiswa maupun dosen ketika menggunakan situs jejaring sosial sebagai media pembelajaran. Hal ini dapat disebabkan karena beberapa fasilitas tersebut sifatnya hanya sebagai pendukung jadi jarang digunakan untuk membantu kegiatan pembelajaran, baik oleh dosen maupun mahasiswa.

\section{KESIMPULAN DAN SARAN}

\subsection{Kesimpulan}

Pada umumnya, mahasiswa menggunakan situs jejaring sosial sebagai sarana mencari informasi dan untuk berkomunikasi, setelah itu baru digunakan untuk keperluan lainnya seperti hobi dan hiburan, atau transaksi bisnis. Hal ini selaras dengan yang diungkapkan oleh (Sopiah, 2013) bahwa mayoritas mahasiswa masih menggunakan situs jejaring sosial untuk keperluan informasi dan komunikasi. Fenomena ini justru mendukung proses pembelajaran yang menggunakan situs jejaring sosial sebagai salah satu media pembelajarannya karena mahasiswa tidak disibukkan dengan aktivitas-aktivitas hobi / bisnis.

Ketika menggunakan situs jejaring sosial sebagai media pembelajaran, hal-hal yang dilakukan oleh mahasiswa adalah mengunggah materi, mengumpulkan tugas, berkomunikasi, dan berdiskusi di dalam forum. Proses pembelajaran biasanya bermula dari dosen yang mengunggah materi melalui group yang sengaja dibuat untuk berkomunikasi antar mahasiswa peserta matakuliah tertentu, kemudian dosen memberikan tugas. Setelah itu mahasiswa dan dosen berkomunikasi, baik via chatting maupun forum, untuk membahas materi dan tugas terkait. Kemudian mahasiswa mengumpulkan tugas yang selesai di kerjakan ke group kelas tersebut.

Situs jejaring sosial memiliki banyak fasilitas yang dapat digunakan oleh penggunanya untuk berkomunikasi dengan rekan / teman lainnya, seperti upload foto dan video, membuat pages, chatting, membuat group, membuat forum diskusi, dan sebagainya. Dari sekian banyak fasilitas tersebut ada dua jenis fasilitas yang banyak digunakan oleh mahasiswa ketika menggunakan situs jejaring sosial sebagai media pembelajarannya, yaitu fasilitas group dan chatting. Kedua fasilitas ini memang paling sesuai dengan konsep pembelajaran yang mereka dapatkan, yaitu menerima 
informasi atau materi dari dosen untuk kemudian didiskusikan bersama dengan dosen maupun mahasiswa lainnya.

\subsection{Saran}

Media pembelajaran berperan penting dalam mendukung kegiatan belajar mengajar yang interaktif, yaitu sebuah aktivitas belajar mengajar yang mendukung komunikasi dua arah antara dosen dan mahasiswa dengan lebih efektif dan efisien. Pemilihan media pembelajaran yang tepat merupakan salah satu faktor yang dapat menentukan kesuksesan pembelajaran yang diselenggarakan oleh perguruan tinggi.

Situs jejaring sosial layak dipertimbangkan sebagai alternatif media pembelajaran yang bisa digunakan oleh dosen di kelas. Sifat dari situs jejaring sosial yang sudah sangat familiar (pervasive) di kalangan mahasiswa dapat dimanfaatkan untuk mendekatkan diri dan menjalin komunikasi dengan mahasiswa sebagai peserta didik. Namun begitu, dosen harus memiliki aturan dan tujuan yang jelas dalam penggunaan situs jejaring sosial sebagai media pembelajaran.

Saat ini situs jejaring sosial hanya dijadikan sebagai media pendamping disamping media pembelajaran yang lain, seperti misalnya email/sistem pembelajaran kelas online. Di masa depan, situs jejaring sosial dapat digunakan secara penuh sebagai satu-satunya media pembelajaran yang digunakan baik di dalam maupun di luar kelas. Masih banyak fasilitas-fasilitas dalam situs jejaring sosial yang belum dimanfaatkan sepenuhnya untuk mendukung kegiatan pembelajaran. Oleh karenanya, baik dosen maupun mahasiswa harus mampu bereksplorasi dalam menggunakan fasilitasfasilitas tersebut sehingga proses pembelajaran menjadi lebih menarik lagi.

\section{UCAPAN TERIMA KASIH}

Penelitian ini didukung oleh Direktorat Penelitian dan Pengabdian Masyarakat (DPPM) Universitas Islam Indonesia dalam skema Hibah Penelitian Dosen Pemula.

\section{DAFTAR PUSTAKA}

Bicen, H. Social network sites usage habits of undergraduate students: case study of Facebook (pp. 943-947), 2011.

Boyd, D. M., \& Ellison, N. B. Social Networking Sites: Definition, History, and Scholarship. Journal of ComputerMediated Communication, 13(1), 210230, 2007.

Brady, K. P., Holcomb, L. B., \& Smith, B. V. The Use of Alternative Social Networking Sites in Higher Educational Settings: A Case Study of the E-Learning Benefits of Ning in Education. Journal of Interactive Online Learning, 9(2), 151-170, 2010.

Cheung, C. M. K., Chiu, P. -Y., \& Lee, M. K. O. Online social networks: Why do students use facebook? Computers in Human Behavior, 27, 1337-1343. http://doi. org/10. 1016/j. chb. 2010. 07. 028, 2011.

Daryanto, D. Media Pembelajaran Peranannya Sangat Penting dalam Mencapai Tujuan Pembelajaran. Yogyakarta: Gaya Media, 2010.

Duggan, M., Ellison, N. B., Lampe, C., Lenhart, A., \& Madden, M. Social Media Site Usage 2014. Retrieved 18 August 2015, from http://www. pewinternet. org/2015/01/09/socialmedia-update-2014/, 2015

Ellison, N. B., Steinfield, C., \& Lampe, C. The benefits of Facebook 'friends:' Social capital and college students' use of online social network sites. Journal of

Computer $<$ unicode $>8208</$ unicode $>$ M ediated Communication, 12(4), $1143<$ unicode $>8211<$ /unicode> 1168 , 2007.

Hoy, M. G., \& Milne, G. Gender Differences in privacy-related 
measures for young adult Facebook users. Journal of Interactive Advertising, 10(2), 28-45, 2010.

Liu, Y. Social media tools as a learning resource. Journal of Educational Technology Development and 3, 101114. Retrieved from http://www. sicet. org/journals/jetde/jetde10/8-Liu. pdf, 2010

Moran, M., Seaman, J., \& Tinti-Kane, H. Teaching, Learning, and Sharing: How Today's Higher Education Faculty Use Social Media. Babson Survey Research Group, (April), 1-16. Retrieved from http://eric. ed. gov/?id=ED535130, 2011.

Pempek, T. a., Yermolayeva, Y. a., \& Calvert, S. L. College students' social networking experiences on Facebook. Journal of Applied Developmental Psychology, 30(3), 227-238. http://doi. org/10. 1016/j. appdev. 2008. 12. 010, 2009.

Rouis, S., Limayem, M., \& Salehi-Sangari, E. Impact of Facebook Usage on Students' Academic Achievement: Roles of Self-Regulation and Trust. Electronic Journal of Research in Educational Psychology, 9(3), 961994, 2011.

Russell, C. A systemic framework for managing e-learning adoption in campus universities: individual strategies in context. Association for Learning Technology Journal, 17(1), 3 19, 2009.

Shen, K. N., \& Khalifa, M. . Facebook Usage Among Arabic College Students: preliminary findings on gender differences, 2010.

Sopiah, N. Faktor-Faktor yang Mempengaruhi Penggunaan Media Facebook. In Proceeding Seminar
Nasional Aplikasi Teknologi Informasi (SNATI) 2013 (pp. 16-20). Universitas Islam Indonesia, 2013.

Sun, P. -C., Tsai, R. J., Finger, G., Chen, Y. -Y., \& Yeh, D. What drives a successful e-Learning? An empirical investigation of the critical factors influencing learner satisfaction. Computers \& Education, 50(4), 11831202, 2008.

www. web. facebook. com. Group Basic. Retrieved 1 January 2015, from https://web. facebook. com/help/162866443847527/, 2015.

www. webopedia. com. What is Chat? Webopedia. Retrieved 17 October 2015, from http://www. webopedia. com/TERM/C/chat. html, 2015. 